\title{
Quantitative RT-PCR analysis of differentially expressed genes in Quercus suber in response to Phytophthora cinnamomi infection
}

\author{
Ghazal Ebadzad $^{1}$ and Alfredo Cravador ${ }^{2^{*}}$
}

\begin{abstract}
cDNA-AFLP methodology was used to gain insight into gene fragments differentially present in the mRNA profiles of Quercus suber roots infected with zoospores of Phytophthora cinnamomi at different post challenge time points. Fifty-three transcript-derived fragments (TDFs) were identified and sequenced. Six candidate genes were selected based on their expression patterns and homology to genes known to play a role in defence. They encode a cinnamyl alcohol dehydrogenase2 (QsCAD2), a protein disulphide isomerase (QsPD), a CC-NBS-LRR resistance protein (QsRPC), a thaumatin-like protein (QsTLP), a chitinase (QsCH) and a 1,3- $\beta$-glucanase (QsG/u). Evaluation of the expression of these genes by quantitative polymerase chain reaction (qPCR) revealed that transcript levels of QsRPC, QsCHI, QsCAD2 and QsPDI increased during the first $24 \mathrm{~h}$ post-inoculation, while those of thaumatin-like protein decreased. No differential expression was observed for 1,3- $\beta$-glucanase (QsG/u).

Four candidate reference genes, polymerase II (QsRPI), eukaryotic translation initiation factor 5A (QsEIF-5A), $\beta$-tubulin (QsTUB) and a medium subunit family protein of clathrin adaptor complexes (QsCACs) were assessed to determine the most stable internal references for qRT-PCR normalization in the Phytophthora-Q. suber pathosystem in root tissues. Those found to be more stable, QsRPII and QsCACS, were used as internal reference in the present work. Knowledge on the Quercus defence mechanisms against biotic stress is scarce. This study provides an insight into the gene profiling of a few important genes of $Q$. suber in response to $P$. cinnamomi infection contributing to the knowledge of the molecular interactions involving Quercus and root pathogens that can be useful in the future to understand the mechanisms underlying oak resistance to soil-borne oomycetes.
\end{abstract}

Keywords: Cork oak; Biotic stress; cDNA-AFLP; qRT-PCR; Defence response; Reference genes

\section{Introduction}

Cork oak (Quercus suber L.) forests are part of Mediterranean ecosystems of Portugal, Spain, France, Italy and Morocco that, besides their high socio-economic value resulting from the exploitation of cork, play a significant ecological role. They are a permanent component of the landscape, a significant barrier against forest fires, and a source of a remarkable biodiversity due to the high habitat heterogeneity (Natividade 1950; Pausas et al. 2009). Especially in Iberian Peninsula that accounts for near $90 \%$ of cork world production and where most studies have been done this ecosystem has been under the threat

\footnotetext{
* Correspondence: acravad@ualg.pt

${ }^{2}$ Centre for Mediterranean Bioresourses and Food, FCT, Universidade do Algarve, Campus de Gambelas, 8005-139 Faro, Portugal

Full list of author information is available at the end of the article
}

of a progressive decline for which the main biological contributing factor was shown to be the root parasite Phytophthora cinnamomi, one of the most destructive Phytophthora species (Brasier et al. 1993; Caetano 2007; Moreira-Marcelino 2001). Despite the ecological and economic importance of cork oak, the pathosystem Quercus-P. cinnamomi has not received sufficient attention and molecular interaction studies are scarce. Also, rising concerns about the expected spread of $P$. cinnamomi to Northern and Eastern regions in Europe, as a consequence of climatic changes (Brasier 2003; Jung 2009) justify the investment in increasing the knowledge of this pathosystem.

Plants use various strategies to resist infection by particular pathogens. These strategies are part of the plants innate immune system. During infection plant pathogen 
secrete effector proteins that reprogramme host physiology and immunity for their benefit. Thus, the pathogen finds its way to counteract the basic defence responses [PAMP-triggered immunity (PTI)] (Jones and Dangl 2006). The next barrier for the pathogen to overcome is the effector-triggered immunity (ETI). This is, however, highly specific and only triggered when the plant carries the so called R genes (plant resistance genes) (Jones and Dangl 2006; Ingle et al. 2006).

Little is known about the genes involved in the $Q$. suber-P. cinnamomi pathosystem. Current knowledge is mainly based on research of the non-host plants such as Arabidopsis. When infected with $P$. cinnamomi, this plant showed initiation of ROS generation, HR activation, lignin synthesis and callose production (Rookes et al. 2008). Other changes such as callose production have also been detected in maize upon infection with $P$. cinnamomi (Hinch and Clarke 1982). However, models using genomics to study the basis of resistance to pathogens and pests are now being developed for Fagaceae species (The Fagaceae Genomic Tools Project http://www.fagaceae.org). Genomics of forest trees entered a new era boosted by the advances in increasingly fast, cost effective and reliable DNA sequencing technologies. Parallel to the development of bioinformatics tools this will allow a major breakthrough in the elucidation of the molecular mechanisms that govern biotic interactions hosted by forest trees (for comprehensive reviews see Neale and Kremer (2011) and Plomion and Fievet (2013).

Understanding the host specific interaction between Q. suber and the pathogen involves studying the genes expressed as a cellular response to the infection, and their role in the plant disease. To date, a number of methods have been successfully developed to identify differential gene expression in various biological systems (Frolov et al. 2003; Venkatesh et al. 2005). For instance, cDNA-AFLP is a reliable, rapid and genome-wide expression technique that helps gene discovery requiring no prior knowledge of gene sequences. Moreover, it is more accurate and reproducible than many other methods as it can amplify low-abundance transcripts (Breyne and Zabeau 2001), although it is necessary to confirm the obtained results by another approach such as qRT-PCR (Mills et al. 2001). In a study by Coelho (2004) several $Q$. suber genes that responded to $P$. cinnamomi infection were identified and characterized. In the current work complementary study was carried out for further understanding the molecular mechanisms underlying the interaction. We report the results of cDNA-AFLP analysis to identify defence related transcripts in micropropagated clonal Q. suber during infection. In addition, for the first time internal reference genes were developed for qRT-PCR normalization in the Phytophthora-Q. suber pathosystem in root tissues and differential gene expression of selected putative defence related genes with regard to different time points of infection was performed by qPCR in Q. suber.

\section{Materials and methods Biological material}

Micropropagated Q. suber plantlets (Clone SSR21) obtained from M.I. Candeias (INIAP, Instituto Nacional de Investigação Agrária e das Pescas, Lisbon) were used for transcript profiling of $Q$. suber genes.

The P. cinnamomi strain PA45 was isolated in the Algarve region (southern Portugal) from soil associated with declining $Q$. suber stands. Isolation and culture maintenance took place on V8 Juice agar medium as described by Horta et al. (2010).

To obtain zoospores, five P. cinnamomi isolate PA45 agar plugs were tacked from the edge of the actively growing colony and placed onto a Miracloth disc (Calbiochem), on a fresh $10 \%$ V8 Agar plate. The procedures followed to produce mycelium mats with sporangia and zoospores were described by Robinson and Cahill (2003).

Biological material used for RNA extraction was prepared by submerging micropropagated roots in a zoospore suspension $(100,000$ zoospores $/ \mathrm{ml})$ for 8, 14, 20, 26 and 32 hours placed in the dark at $25^{\circ} \mathrm{C}$. Non-inoculated roots, submerged in sterile distilled water were used as control.

\section{Total RNA extraction}

Total RNA was extracted from $50 \mathrm{mg}$ of micropropagated clonal cork oak roots with the RNeasy kit from Qiagen, according to the instructions supplied by the manufacturer (Dudareva et al. 1996). Traces of DNA were removed with $2 \mu \mathrm{l}$ DNase I (1 U/ $\mu \mathrm{L}$, Invitrogen), in the presence of $2 \mu \mathrm{l}$ RNaseout (40 U/ $/ \mathrm{L}$, Invitrogen) in $10 \mu \mathrm{l}$ DNase buffer (200 mM Tris-HCl, pH 8.4, $20 \mathrm{mM}$ $\mathrm{MgCl}_{2}, 500 \mathrm{mM} \mathrm{KCl}$, Invitrogen). RNA purity and integrity is essential for synthesis of full-length cDNA. Concentration of total RNA were determined by measuring the absorbance at $260 \mathrm{~nm}$ and the ratio of the absorbance at $260 / 280 \mathrm{~nm}$ was used to assess the RNA purity in a spectrophotometer MBA 2000 (Perkin Elmer). RNA was considered pure when a ratio of $\sim 2.0$ was obtained. As a routine procedure the integrity of total RNA was checked by electrophoresis in a denaturing $1.2 \%$ agarose gel, stained with ethidium bromide (Sambrook and Russell 2001).

\section{CDNA synthesis and production of AFLP fragments}

Double-stranded cDNA was synthesized from $2 \mu \mathrm{g}$ of total RNA with the cDNA Synthesis System (Roche), with modifications to the original protocol supplied by the manufacturer. Synthesis of the first cDNA strand was initiated using the primer COE [5'AGTGAATTCT12V $(\mathrm{V}=\mathrm{A}, \mathrm{C}, \mathrm{G})]$, composed of a mixture of the three oligonucleotides (Money et al. 1996). Synthesis of the second 
cDNA strand and digestion of residual RNA were performed according to the kit protocol (Gubler 1988; Gubler and Hoffman 1983). The cDNA was purified with the Qiaquick PCR purification kit according to the protocol supplied by the manufacturer. The cDNA was removed from the column with $50 \mu \mathrm{l}$ of Tris- $\mathrm{HCl}(10 \mathrm{mM}, \mathrm{pH} 8.5)$ and the solution was dehydrated by centrifugation under vacuum to a volume of $20 \mu$ l.

The purified cDNA was double digested with $2.5 \mathrm{U}$ each of $E c o$ RI and $M s e I$ in the presence of 5 times reaction buffer $(50 \mathrm{mM}$ Tris- $\mathrm{HCl}, \mathrm{pH} 7.5,50 \mathrm{mM} \mathrm{Mg}$-acetate, $250 \mathrm{mM} \mathrm{K}$-acetate) for $2 \mathrm{~h}$ at $37^{\circ} \mathrm{C}$. The enzymes were then inactivated for $15 \mathrm{~min}$ at $70^{\circ} \mathrm{C}$. After inactivation of endonucleases, adapters complementary to the restriction sites EcoRI and MseI were ligated to the digested material. Ligation was performed in the presence of 5 pmol EcoRI adapter (5'-AATTGGTACG CAGTCTAC-3', 5'-CTCGTAGACTGCGTACC-3'), 50 pmol Mse I adapter (5' - TACTCAGGACTCAT- 3', 5' GACGATGAGTCCTGAG- 3'), $24 \mu \mathrm{l}$ ligase buffer composed of ATP $(0.4 \mathrm{mM})$, Tris- $\mathrm{HCl} \mathrm{pH} \mathrm{7.5,} \mathrm{Mg-acetate}$ $(10 \mathrm{mM})$, and $\mathrm{K}$-acetate $(50 \mathrm{mM})$ and $1 \mathrm{U}$ T4 DNA ligase at $37^{\circ} \mathrm{C}$ for $2 \mathrm{~h}$ (AFLP Core Reagent Kit, Invitrogen) (Bachem et al. 1998). The resulting ligated cDNA was pre-amplified with primers that hybridize to the adaptors. Pre-amplification reaction was performed in a total volume of $50 \mu \mathrm{l}$ including $5 \mu \mathrm{l}$ of 10 times buffer [Tris- $\mathrm{HCl}$ (100 mM, pH 8.3), $\mathrm{MgCl}_{2}$ (15 mM), KCl (500 mM)], 0.2 $\mu \mathrm{l}$ Taq DNA polymerase ( $5 \mathrm{U} / \mu \mathrm{l}$, Boehringer Mannheim), 15 pmol of primer EcoRI +0 (5'-GACTGCGTAC CAATTC-3'), 15 pmol of MseI + 0 primer (5'-GAT GAGTCCTGAGTAA-3') and $10 \mu \mathrm{l}$ of cDNA solution prepared above. The reaction was carried out in 28 cycles consisting of $30 \mathrm{~s} 94^{\circ} \mathrm{C}, 60 \mathrm{~s} 60^{\circ} \mathrm{C}, 60 \mathrm{~s} 72^{\circ} \mathrm{C}$ (Zabeau and Vos 1993).

The pre-amplified cDNA was diluted in water in a ratio of 1:10 and used as a target for the selective amplification which involved the use of combinations of EcoRI and MseI primers containing one, two or three selective bases at the 3 ' end. In total, twenty pairs of primers were used in selective amplifications. The EcoRI primers were radiolabelled with $\left[\gamma^{33} \mathrm{P}\right]$ ATP (Redivue, Amersham Pharmacia) at the $5^{\prime}$ end using standard protocols (Bachem et al. 1998; Zabeau and Vos 1993). Labelled selective amplification products were separated on standard $6 \%$ polyacrylamide sequencing gels. After electrophoresis, the gels were dried on filter paper (3MM paper; Whatman) and exposed to X-ray film for $30 \mathrm{~h}$. The cDNA fragments were visualised by autoradiography, after positional marking the gel and the film.

\section{Isolation, cloning and sequencing of cDNA fragments} Those gene fragments present only in the mRNA profile of roots infected with $P$. cinnamomi and those that showed an increase or decrease in their expression were eluted from the gel. Rectangular pieces of Whatman paper were placed into tubes with the piece of excised gel in $40 \mu \mathrm{l}$ water and kept on ice for $10 \mathrm{~min}$. After hydration, the tubes were placed at $95^{\circ} \mathrm{C}$ for $15 \mathrm{~min}$ and transferred to ice. The mixture was centrifuged for a few seconds, the supernatant was collected and $5 \mu \mathrm{l}$ of the solution were used as target DNA, in reamplification reactions (Habu and Iida 1998). These were performed with the selective primers used to generate the corresponding cDNA-AFLP profile. The re-amplified PCR products were run on a $2 \%$ agarose gel, excised and purified with the Qiaquick PCR Purification Kit (Qiagen) and cloned into the pCRII Topo vector, with the TA Cloning Kit (Invitrogen). Manufacturer's instructions for these kits were followed throughout. The fragments were sequenced using the kit ABI PRISM BigDye Terminator Cycle Sequencing Ready Reaction (Perkin Elmer/Applied Biosystems) in an automatic sequencer ABI PRISM 377 (Perkin-Elmer) at Macrogen Company (Seoul, Korea).

\section{Sequence analysis}

The sequences were analyzed by means of the Vector NTI 6 software $^{\text {mx }}$ (InforMax. Inc) and were aligned and compared through the National Centre for Biotechnology Information (NCBI) GenBank using the tblastx or blastn algorithms. Further analysis for selection of interesting cDNA-AFLP expression patterns in the time-course of the CDNA-AFLP experiment was done on the basis of significant tblastx or blastn hits sequence alignment score (e-values <0.01) (Altschul et al. 1997), and homolog to genes known to play a role in disease/defence in plants. Each transcript was functionally annotated through analysis of the scientific literature. A summary of selected cDNA-AFLP fragments assigned to different functional categories is shown in Additional file 1.

\section{Complete sequencing of coding regions of Quercus suber genes}

Among the candidate genes corresponding to the differentially expressed $Q$. suber fragments in response to P. cinnamomi, four TDFs (Clone 27-2, Clone 29-1, Clone $59-1$ and Clone $60-1$ ) which respectively have similarity with genes encoding $1,3-\beta$-glucanase, alcohol dehydrogenase, thaumatin-like protein and chitinase were selected to identify their full-length $3^{\prime}$ and $5^{\prime}$ end.

A Full Length cDNA Library was constructed by Invitrogen using SuperscriptR Full Length cDNA Library Construction Kit. This library is guaranteed to have at least $3 \times 10^{6}$ clones with an average insert size of $1.2 \mathrm{~kb}$. Quality checks were performed and data were included in the certificate of analysis. The library screening was performed by PCR amplification. 
Based on the titer of the cDNA Library on the Certificate of Analysis $\left(1.5 \times 10^{6} \mathrm{cfu} / \mathrm{ml}\right)$, a dilution of 1:10 was prepared and incubated at $99^{\circ} \mathrm{C}$ for $5 \mathrm{~min}$ and then placed on ice for $2 \mathrm{~min}$. Five $\mu \mathrm{l}$ of dilution were used as a template in a PCR reaction which was carried out in $50 \mu \mathrm{l}$ volumes containing $5 \mu \mathrm{l}$ buffer $10 \times(200 \mathrm{mM}$ Tris $-\mathrm{HCl}$, $\mathrm{pH}$ 7.5, $1 \mathrm{M} \mathrm{KCl}, 15 \mathrm{mM} \mathrm{MgCl}$, DTT $10 \mathrm{mM}, 1 \mathrm{mM}$ EDTA, Tween 20, 1\% v/v, Nonidet P40 1\% v/v), $5 \mu \mathrm{l}$ dNTPs (dATP, dCTP, dGTP and dTTP, $2 \mathrm{mM}$ each), $0.2 \mu \mathrm{l}$ Taq DNA polymerase $(5 \mathrm{U} / \mu \mathrm{l}$, Boehringer Mannheim) and with $2 \mu \mathrm{l}$ each specific primer $(10 \mathrm{mM})$ (primers specifically designed to hybridize to candidate genes for amplification of their $3^{\prime}$ and $5^{\prime}$ end) and $2 \mu \mathrm{l}$ M13 forward and M13 reverse primers which hybridize with regions of the $\mathrm{pDONR}^{\mathrm{Tm}} 222$ vector used for cloning the double strand cDNAs in the construction of cDNA library by Invitrogen. Amplification reactions were performed using the following cycling parameters: 35 cycles of $30 \mathrm{~s}$ at $94^{\circ} \mathrm{C}, 30 \mathrm{~s}$ at $60^{\circ} \mathrm{C}$ and $2 \mathrm{~min}$ at $68^{\circ} \mathrm{C}$. When no amplification was observed, reamplification was carried out by using $5 \mu \mathrm{l}$ of the PCR product from the first reaction under the same conditions. Ten $\mu \mathrm{l}$ of each reaction was applied to a $1.5 \%$ agarose gel, an electrophoresis was run and the result analyzed. In order to amplify the coding sequences (CDS) of the above referred to selected candidate genes corresponding to the differentially expressed Q. suber fragments in response to $P$. cinnamomi, primers were designed based on known sequences of $3^{\prime}$ and $5^{\prime}$ ends. The fragments were cloned into vector pCRII Top Kit Top TA Cloning Invitrogen (Ausubel et al. 1994; Shuman 1994). Full CDS sequences of the selected genes were analyzed in blastn available at NCBI (National Center for Biotechnology Information) (Altschul et al. 1997) and multisequence alignment of nucleotide was carried out using Vector NTI7 of InforMax, Inc.

The cloned sequences were submitted to the NCBI public database (http://blast.ncbi.nlm.nih.gov/). Description of genes amplified and sequence accession numbers are shown in Table 1.

\section{Quantitative real-time RT-PCR (qRT-PCR) Biological material}

In order to infect roots with mycelium of P. cinnamomi, germinated roots with $10 \mathrm{~cm}$ length and 2-week-old were infected directly by placing a $8 \mathrm{~mm}$ diameter V8 agar plug containing actively growing mycelium in direct contact with the root surface. Roots were collected at 6 , 12, 18 and 24 hours post-inoculation (hpi). Uninfected roots at time zero were used as control for comparison of expression pattern of target genes in infected and uninfected roots. For each time point, four cork oak roots were used as biological replicates in the qPCR reaction.

\section{Total RNA extraction and purification}

Total RNA was extracted from healthy and infected roots and trace of genomic DNA eliminated as described above. After elimination of gDNA contamination, the total RNA was purified using polyvinylpyrrolidone (PVP) which is known to remove polysaccharides, phenols and other compounds (Ainsworth 1999; Asif et al. 2000) and then cleaned up by phenol:chloroform extraction. This method was combined with RNeasy kit (Qiagen) for purification of RNA.

RNA concentration was determined spectrophotometrically using nanodrop ND-1000 (Thermo Scientific) and RNA quality was assessed by electrophoresis in denaturing $1.2 \%$ agarose gel.

\section{First strand CDNA synthesis and quality control}

First strand cDNA synthesis was carried out on 500 ng total RNA from each sample, using RevertAid First Strand cDNA Synthesis Kit according to the protocol supplied by the manufacturer.

The presence of inhibitors within biological samples was assessed using as an external control, the Alien qRT-PCR Inhibitor Alert (Agilent Technologies). ALIEN RNA was added to each sample during first strand cDNA synthesis and a tube containing only the ALIEN RNA was reverse transcribed as a control following the protocol supplied by the manufacturer.

\section{Reference genes}

Four reference genes [encoding RNA polymerase II (QsRP II), eukaryotic translation initiation factor $5 \mathrm{~A}$ (QSEIF-5A), $\beta$-tubulin (QSTUB) and clathrin adaptor complexes medium subunit family protein (QsCACs)] were selected according to criteria described below, and their consistent PCR amplification was checked. Sequences were obtained from the Fagaceae database, Fagaceae Genome Web (The Fagaceae Genomic Tools Project http://www. fagaceae.org) and from GenBank. All the reference genes were cloned and sequenced. The sequence accession numbers are shown in Table 1.

Analysis of the stability of genes was carried out using the software GenEx (Version 5. 4. 3, MultiD Analyses, Gothenburg, Sweden), that includes both GeNorm and Normfinder programmes for selection of optimal reference genes where two parameters were defined: $M$ (average expression stability) and stability value. Lower $M$ or stability value indicates more stable expression, increasing the suitability of a particular gene as a control gene.

\section{Primer design}

Gene-specific primers were designed to target sequences of $Q$. suber candidate genes and potential reference genes to amplify amplicons ranging from 86 to $229 \mathrm{bp}$ (Table 2), based on conserved regions of orthologous 
Table 1 Description of target and reference genes amplified in Quercus suber

\begin{tabular}{|c|c|c|c|}
\hline Target genes (TDF code) & Homology & $\begin{array}{l}\text { Accession } \\
\text { number }\end{array}$ & $\begin{array}{l}\text { Amplicon } \\
\text { length (bp) }\end{array}$ \\
\hline 1,3-beta glucanase (QsGlu) (clone 27-2) & $\begin{array}{l}\text { Ricinus communis glucan endo-1,3- } \beta \text {-glucosidase } \\
\text { (XM_002518884.1) }\end{array}$ & KF704744 & 1230 \\
\hline Alcohol dehydrogenase (QsADH) (clone 29-1) & Dimocarpus longan alcohol dehydrogenase (DQ515803.1) & KF704745 & 1146 \\
\hline Thaumatin-like protein (QsTLP) (clone 59-1) & $\begin{array}{l}\text { Cucumis sativus thaumatin-like protein [(LOC101227447), } \\
\text { (XM_004163769.1)] }\end{array}$ & KF704742 & 750 \\
\hline Chitinase (QsCHI) (clone 60-1) & $\begin{array}{l}\text { Fragaria vesca subsp. vesca chitinase-like protein 2-like } \\
\text { (XM_004295058.1) }\end{array}$ & KF704743 & 951 \\
\hline \multicolumn{4}{|l|}{ Reference genes } \\
\hline RNA polymerase II (QsRPII) & - & KJ563261 & 954 \\
\hline$\beta$-tubulin (QsTUB) & - & KJ563262 & 1341 \\
\hline Eukaryotic translation initiation factor 5A (QsEIF-5A) & - & KJ563263 & 811 \\
\hline $\begin{array}{l}\text { Clathrin adaptor complexes medium subunit family } \\
\text { protein (QsCACS) }\end{array}$ & - & ID6728500 & 175 \\
\hline
\end{tabular}

For the target genes, amplicon sizes were calculated based on the complete coding region sequences (CDS).

genes from other plant families present in the GenBank database. All primers were designed using primer 3 (v. 0.4.0) software (http://frodo.wi.mit.edu/) (Rozen and Skaletsky 2000) and tested for their specificity by comparing with the genome sequences of $P$. cinnamomi, running PCR, using cDNAs of infected cork oak roots as templates and sequencing the amplicons. On the basis of these analyses the primers were judged to be specific for their target cDNA templates.

PCR efficiencies and coefficients of primers were determined with duplicated standard curves generated from 10-fold dilution series (from $1 \mathrm{ng}$ to $1 \mathrm{fg}$ ) of purified PCR fragments as templates. Amplification efficiencies for each gene and coefficients of determination $\left(\mathrm{r}^{2}\right)$ between concentration and signal intensity were calculated from the slopes of the standard curves for all genes.

\section{QPCR amplification}

Quantitative RT-PCR reactions were performed in an iQ5 multicolour Real-Time PCR Detection System (Bio-Rad) using SsoFast ${ }^{\mathrm{Tm}}$ Evagreen $^{\bullet}$ supermix kit (Biorad). For each experimental sample $2 \mu \mathrm{l}$ of diluted cDNA (2.5 ng), $7.5 \mu \mathrm{l}$ of SsoFast $^{\mathrm{Tm}}$ Evagreen $^{\odot}$ supermix, $1 \mu \mathrm{l}$ of forward primer and $1 \mu \mathrm{l}$ of reverse primer (final concentration $50 \mathrm{nM}$ each primer) in a final volume of $15 \mu \mathrm{l}$ were used. The following standard thermal cycling profile was used: $95^{\circ} \mathrm{C}$ for $10 \mathrm{~min} ; 30 \mathrm{~s}$ at $95^{\circ} \mathrm{C}, 40$ cycles of $1 \mathrm{~min}$ at optimal annealing temperature for each pair of primer and $30 \mathrm{~s}$ at $72^{\circ} \mathrm{C}$. To confirm that the signals were the result of a single amplified product, melting curve analysis was performed after the run by increasing the temperature of $0.5^{\circ} \mathrm{C}$ by cycle from $65^{\circ} \mathrm{C}$ to $95^{\circ} \mathrm{C}$. To estimate variation in the technique, two technical replicates were carried out for each biological replicate and four biological replicates were used for each time point of infection $(6,12,18$ and $24 \mathrm{hpi}$ ) and non-infected roots (time 0 ).

Expression levels were determined as the number of cycles $(\mathrm{Ct})$ needed for the amplification to reach a threshold fixed in the exponential phase of PCR reaction (Walker 2002). For each repetition of samples in every run, the level of gene expression was normalized to that of QsRP II and QsCACs by means of "Ct of target-Ct of reference gene" formula namely $\Delta \mathrm{Ct}$. Furthermore, the mean of $\Delta \mathrm{Ct}$ values for each target gene was then normalized to the expression of infected samples with noninfected samples to find $\Delta \Delta \mathrm{Cq}$. This accounted for any effects associated with the experimental procedure and was expressed as the ratio of the targeted $\Delta C q$ expression to the non-targeted $\Delta \mathrm{Cq}$ expression method described by Applied Biosystems.

QsRPII and QsCACs housekeeping genes were chosen based on geNorm and NormFinder algorithm available in GenEx (Version 5.4.3, MultiD Analyses, Gothenburg, Sweden) for normalization of real-time quantitative RTPCR data.

\section{Statistical analysis}

Temporal expression data was analyzed using SPSS (SPSS ver. 20). One-way analysis of variance (ANOVA) with Tukey's post hoc tests was used to reveal significant differences.

\section{Results and discussion}

Transcript profiling of $Q$. suber genes in response to Phytophthora cinnamomi infection

The molecular mechanisms underlying Quercus-soil-borne pathogens interaction is largely unknown. The cDNAAFLP methodology is a simple, rapid and very powerful tool for discovery of novel genes in organisms especially when little is known about the genome sequences (Breyne 
Table 2 Description of primers used in RT-qPCR

\begin{tabular}{|c|c|c|c|c|c|c|}
\hline Target genes & $\begin{array}{l}\text { Accession } \\
\text { number }\end{array}$ & Primer sequence & $\begin{array}{l}\text { Amplicon } \\
\text { size (bp) }\end{array}$ & $\begin{array}{l}\text { Temperature } \\
\left({ }^{\circ} \mathrm{C}\right)\end{array}$ & Efficiency & $r^{2}$ \\
\hline \multicolumn{7}{|l|}{ Reverse: 5'TGAGGTTITGAAACCCCTTG3' } \\
\hline \multirow[t]{2}{*}{ Thaumatin like protein $(Q s T L P)^{\mathrm{a}}$} & \multirow[t]{2}{*}{ KF704742 } & Forward: 5TCGGTCCCATGATAATAGAAG3' & \multirow[t]{2}{*}{207} & \multirow[t]{2}{*}{55} & \multirow[t]{2}{*}{$90.4 \%$} & \multirow[t]{2}{*}{0.998} \\
\hline & & Reverse: 5'TTGCCACCGGTGCAAGTAG3' & & & & \\
\hline \multirow[t]{2}{*}{ Chitinase $(\mathrm{Qs} C H)^{a}$} & \multirow[t]{2}{*}{ KF704743 } & Forward: 5'CCGTGGTGCCTTGCCTTTG3' & \multirow[t]{2}{*}{177} & \multirow[t]{2}{*}{55} & \multirow[t]{2}{*}{$96.0 \%$} & \multirow[t]{2}{*}{0.994} \\
\hline & & Reverse: 5'GCATCATGTGCTGAAGGCTG3' & & & & \\
\hline \multirow[t]{2}{*}{ 1,3- $\beta$-glucanase $(Q s G / u)^{\mathrm{a}}$} & \multirow[t]{2}{*}{ KF704744 } & Forward: 5'CACTCTCACTGGTTGTCTTG3' & \multirow[t]{2}{*}{175} & \multirow[t]{2}{*}{55} & \multirow[t]{2}{*}{$93.6 \%$} & \multirow[t]{2}{*}{0.996} \\
\hline & & Reverse: 5'CGGGGCTATGCAGCTGGTC3' & & & & \\
\hline \multirow{2}{*}{$\begin{array}{l}\text { Cinnamyl alcohol dehdrogenase } 2 \\
(Q s C A D 2)^{b}\end{array}$} & \multirow[t]{2}{*}{ AY362455 } & Forward: 5'AGCGGGTAGTTGTGACATCC3' & \multirow[t]{2}{*}{229} & \multirow[t]{2}{*}{55} & \multirow[t]{2}{*}{$93.8 \%$} & \multirow[t]{2}{*}{0.998} \\
\hline & & Reverse: 5'AGAGGACCAATCACCATTGC3' & & & & \\
\hline \multirow[t]{2}{*}{ Protein disulphide isomerase $(Q s P D)^{b}$} & \multirow{2}{*}{$\begin{array}{l}\text { AY525090; } \\
\text { AJ316614 }\end{array}$} & Forward: 5'GCCACTGGGAAGGTTGTGAC3' & \multirow[t]{2}{*}{221} & \multirow[t]{2}{*}{55} & \multirow[t]{2}{*}{$94.9 \%$} & \multirow[t]{2}{*}{0.998} \\
\hline & & Reverse: 5'GTTITGCCTTCAAGCTCAGG3' & & & & \\
\hline \multirow[t]{2}{*}{ CC-NBS-LRR resistance protein $(Q s R P C)^{b}$} & \multirow[t]{2}{*}{ GU289638 } & Forward: 5'GTTGCAACAACCCACTTCTC3' & \multirow[t]{2}{*}{182} & 55 & $90.0 \%$ & 0.994 \\
\hline & & Reverse: 5TGAGGTTITGAAACCCCTTG3' & & & & \\
\hline Reference genes & & Primer sequence & $\begin{array}{l}\text { Amplicon } \\
\text { size (bp) }\end{array}$ & $\begin{array}{l}\text { Temperature } \\
\left({ }^{\circ} \mathrm{C}\right)\end{array}$ & Efficiency & $r^{2}$ \\
\hline RNA polymerase II (QsRPII) & KJ563261 & Forward: 5'GACATAGATCCCGTTACCCA3' & 168 & 55 & $92.3 \%$ & 0.999 \\
\hline & & Reverse: 5'TTTGATTGCACCAGTAGATTC3' & & & & \\
\hline$\beta$-tubulin (QsTUB) & KJ563262 & Forward: 5'GCTCACTACCCCAAGCTTT3' & 187 & 55 & $90.5 \%$ & 0.999 \\
\hline & & Reverse: 5'GGAACCTCTGGAGGTTAAA3' & & & & \\
\hline Eukaryotic translation initiation factor $5 \mathrm{~A}$ & KJ563263 & Forward: 5'GCCATGTCCGACGAGGAG3' & 86 & 57 & $90.2 \%$ & 1 \\
\hline & & Reverse: 5'CGGATGGTTCCGGCTTGC3' & & & & \\
\hline $\begin{array}{l}\text { Clathrin adaptor complexes medium } \\
\text { subunit family protein }(Q s C A C S)^{c}\end{array}$ & ID6728500 & $\begin{array}{l}\text { Forward: 5TCTGGGAGAAGAGTGGC } \\
\text { TACA3' }\end{array}$ & 175 & 55 & $96.3 \%$ & 0.993 \\
\hline & & Reverse: 5'GAGCCACCATTCAAATCCT3' & & & & \\
\hline
\end{tabular}

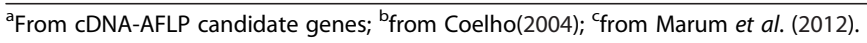

and Zabeau 2001). In this study, a cDNA-AFLP analysis of differential gene expression in clonal cork oak roots response to $P$. cinnamomi was conducted. Selective amplification with 20 primer combinations allowed the visualization of 53 transcript-derived fragments (TDFs) with 47-485 bp size (Figure 1). These fragments were sequenced and the sequences further analyzed by blastn and blastx. A homology search showed that among the determined sequences, $66 \%$ were homologous to known sequences while $26.5 \%$ were homologous to genes with unknown function and $7.5 \%$ had no matches with databases. Among these TDFs, 92.5\% were related to $Q$. suber and $7.5 \%$ were attributed to P. cinnamomi.

A summary of most interesting selected cDNA-AFLP fragments and their annotation is shown in Additional file 1 .

TDFs (Clone 27-2, Clone 59-1 and Clone 60-1) which have direct blast hits to known annotated genes that play a role in disease/defence in plants were selected for the following analysis. These derived from genes that encode 1,3-beta glucanase, thaumatin-like protein and chitinase, respectively. They represent various functions assigned to proteins deduced from these genes such as activation of defence signalling pathways, anti-fungal activity [ex. 1,3- $\beta$-glucanase, chitinase (Mauch and Staehelin 1989) and thaumatin like protein (Kim et al. 2009)].

In order to accurately assess differential expression patterns of genes revealed by cDNA-AFLP, qRT-PCR evaluation of these and of additional three genes was further conducted. As a first step, to avoid bias, reliable reference genes to be used as internal controls were judiciously selected and validated.

\section{Gene expression analysis by qRT-PCR and selection and validation of reference genes}

In a previous study, QsCACs and actin were described as good reference genes in Q. suber (Marum et al. 2012). They were evaluated among several others, in several tissues that did not include roots. Whenever analysing transcript expression levels by RT-qPCR in different tissues and under different conditions a new evaluation of reference genes is required. This is the case of $Q$. 

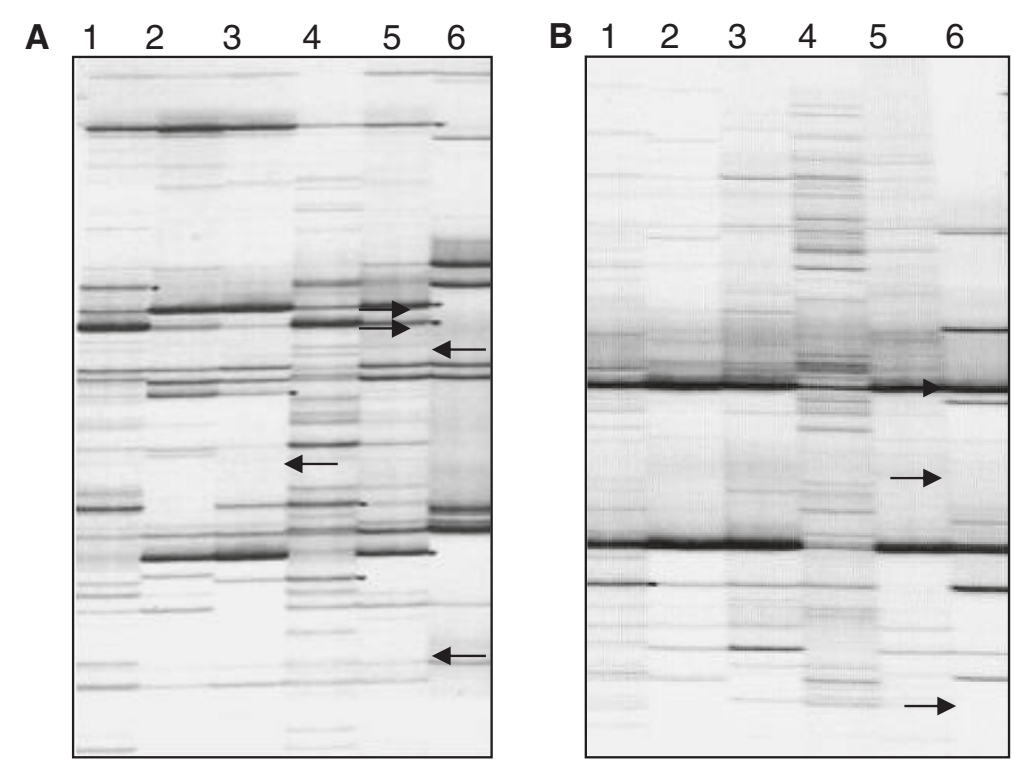

Figure 1 Comparing CDNA-AFLP fragments derived from micropropagated Quercus suber roots, before and after inoculation with zoospores from Phytophthora cinnamomi. The examples show selective amplification with primer combinations ECoRI-ACC/Msel-CTA (A) and EcoRl-ATG/Msel-CAA (B) in host roots cells at 0, 8, 14, 20, 26 and $32 \mathrm{~h}$ post challenge (from 1 to 6, respectively). Examples of differentially expressed fragments are indicated by arrows in black.

suber roots challenged with $P$. cinnamomi infection that involves substantial changes in the process under study compared with the above study.

QsRPII, QsCACs, QsTUB and QsEIF-5A were selected based on their previous use as internal controls in gene expression studies of species such as Q. suber, Prunus persica and Musa acuminata (Marum et al. 2012; Tong et al. 2009; Chen et al. 2011) and on their consistent PCR amplification. The stability of these potential reference genes was analyzed using GenEx (Version 5.4.3, MultiD Analyses, Gothenburg, Sweden). M values of all selected reference genes were lower than 1 , attesting they are stably expressed housekeeping genes in our samples. QsRPII and QsCACs were the two most stable genes with an equal $M$ value of 0.247. QsTUB and QSEIF-5A were the third and the fourth most stable genes, with $M$ values of 0.483 and 0.744 , respectively.

In the relative quantification of gene expression, the use of multiple reference genes that are stable under a given experimental condition was proven to be an efficient method for the normalization of RT-qPCR (Migocka and Papierniak 2011; Demidenko et al. 2011; Die et al. 2010; Xu et al. 2011; Expósito-Rodríguez et al. 2008; Schmidt and Delaney 2010). In order to determine how many reference genes should be included in the normalization process, Acc.SD of the four genes were calculated by NormFinder algorithm available in GenEx (Version 5.4.3, MultiD Analyses, Gothenburg, Sweden). The optimal number of reference genes is indicated by the lowest value for the Acc.SD. This was found when using two reference genes among the four reference genes. The improvement of using two reference genes (Acc.SD = 0.1087) instead of only one (Acc.SD = 0.1234) is very small. Nevertheless, in order to avoid the weakness of using one single reference gene and for more accurate normalization of the qRT-PCR data (Die and Rowland 2013), the combination of two control genes QsRPII and QsCACs according to M-value and Acc.SD values was used for normalization of data. These results are valuable data for future studies on gene expression in this or eventually, other pathosystems involving oaks.

The specificity of PCR amplification of each primer pair was confirmed by sequencing of PCR products and by melting curve analysis during real-time PCR. Amplification efficiencies during different PCR runs varied between $90 \%$ and $96.3 \%$, and the $\mathrm{r}^{2}$ values varied from 0.993 to 1 as described in Table 2. These make the normalized expression ratios reliable and accurate.

The relative expression analyses of six genes of Q. suber by qRT-PCR were conducted at $0,6,12,18$ and 24 hpi in order to validate the cDNA-AFLP results. Gene expression was calculated as the ratio between target gene transcript number and RNA polymerase II (QsRPII) and clathrin adaptor complexes medium subunit family protein (QsCACs) transcripts as reference genes. Defence-related genes coding for thaumatinlike protein $(Q s T L P)$, chitinase ( $Q s C H I), 1,3-\beta$-glucanase (QsGlu), a cinnamyl alcohol dehydrogenase2 (QsCAD2), a protein disulphide isomerase (QSPDI) and a NBS-LRR resistance protein $(Q s R P c)$ were chosen for evaluation of 
their expression by qRT-PCR. The latter three genes have been previously identified by cDNA-AFLP and characterized (Coelho 2004). We decided to select them due to their potential important role in the defence response of cells against plant pathogens as shown in previous studies (Coll et al. 2011; Meyers et al. 1999, 2003; Kohler et al. 2008; Soriano et al. 2005; Radwan et al. 2008; Chandra et al. 2007; Hammond-Kosack and Jones 1997; Milcevicova et al. 2010; Vieira Dos Santos and Rey 2006; Lamb and Dixon 1997; Garin et al. 2001; Muller-Taubenberger et al. 2001; Augusto et al. 2002; Nathan and Hibbs 1991; Ray et al. 2003; Nwugo et al. 2013).

The transcript profiles of $Q s R P c, Q s C A D 2, Q s P D I$ and $Q s C H I$ showed a significant up-regulation following inoculation $(P<0.05)$ (Figure 2a, b, c and d). The most significant up-regulation was observed in the transcript profile of QsRPc gene which showed a 7.54-fold higher expression level at $24 \mathrm{hpi}$ as compared to its expression in healthy roots at time 0. QsCAD2 and QsPDI exhibited significant increases by 2.74 -fold and 3.22 -fold, at 24 hpi, respectively, as opposed to the uninfected sample (Figure 2b and c). QsCHI expression showed a constant expression pattern up to $18 \mathrm{hpi}$, followed by a significant up-regulation of 2.6 -fold at $24 \mathrm{hpi}$, compared to time 0 (Figure 2d). In contrast the expression of QsTLP was down regulated, exhibiting a significant decrease at 24 hpi (Figure 2e). No significant difference in expression of QsGlu, between infected and healthy roots was observed (Figure 2f). QRT-PCR confirmed the expected up-regulation for $Q s R P c$, QsCAD2, QsPDI and QsCHI and the down-regulation for QSTLP showed by cDNAAFLP. On the contrary, unexpectedly, QsGlu showed no differential expression by qRT-PCR being probably a false positive in CDNA-AFLP analysis.

$R$ proteins have been attributed the function of recognizing specific pathogen effectors, assuming the role of the so called effector-triggered immunity (ETI) resulting often in the induction of hypersensitive response (HR) and programmed cell death (PCD) (Coll et al. 2011).

Resistance gene families have been evaluated in numerous plants including A. thaliana (Meyers et al. 1999, 2003), Populus trichocarpa (Kohler et al. 2008) and Prunus armeniaca L. (Soriano et al. 2005). The majority of plant disease resistance genes identified to date code to proteins belonging to a limited number of structural classes, of which those containing nucleotide binding site (NBS) motifs are the most common. Classification of these proteins is based primarily on predicted domains and motifs. (Hulbert et al. 2001).

In the present work one of the most important identified gene is the one encoding a resistance protein $(Q s R P c)$ up-regulated upon infection by P. cinnamomi. This gene was shown to be $4275 \mathrm{bp}$ long, to comprise an ORF encoding a polypeptide of 1425 amino acid (GenBank accession number-GU289638) and shows all the motifs characteristic of a CC-NBS-LRR resistance gene subclasse (Coelho 2004). The notable 7.5-fold expression increase of this gene at 24 hpi when compared with the control, suggests the expressed protein acts as a putative host target to effectors produced by the pathogen $P$. cinnamomi during infection and results in defence response in $Q$. suber against the pathogen attack. CC-NBS-LRR genes are part of a large family in which some members can be down-regulated as illustrated in the interaction $Q$. suber-Pisolithus tinctorius and $Q$. robur-Microsphaera alphitoides reported by Sebastiana et al.(2014) and Kurth et al. (2014), respectively.

It is known that the defence system in plants has multiple forms; one of these forms is the activation, during infection, of the transcription of genes involved in the synthesis of phenolic compounds as precursors for suberin and lignin production (Chandra et al. 2007; Hammond-Kosack and Jones 1997; Milcevicova et al. 2010). Lignin and suberin which are used as structural components of plant cell walls act as a physical barrier blocking the entry of the pathogen. Enzymes, like peroxidases, cinnamyl alcohol dehydrogenases and phenylalanine ammonia-lyases, participate in the phenylpropanoid metabolism. Therefore, the up-regulation of the expression of cinnamyl alcohol dehydrogenase2 (QsCAD2) upon infection by $P$. cinnamomi could be the manifestation of its participation in this metabolism as a response to the attack by the oomycete. The gene encoding QsCAD2 was previously identified in cork oak (GenBank accession no: AY362455). This gene contains the catalytic domain for binding of zinc ion and the binding domain for NADP cofactor (Coelho 2004). We report now accurately its up-regulation by qRT-PCR, showing its role in the defence response of cork oak.

The protein disulphide isomerase gene ( $Q s P D I)$ was shown to be 3098 bp long and to comprise an ORF encoding a polypeptide of 507 amino acid (AY525090; AJ316614) containing the WC(G/P)PC motif and three repeated thiorredoxin domains (Coelho 2004). QsPDI expression increased $24 \mathrm{~h}$ after infection, suggesting this gene can be activated by oxidation or reduction and/or isomerisation of cysteine residues, transcription factors and other proteins involved in the cellular response to the oxidative burst that occurs after pathogen invasion (Vieira Dos Santos and Rey 2006). Reactive oxygen species (ROS) induced in plants upon infection usually cause damage to pathogens. In addition, ROS (and redox signals) behave as a second messenger participating in different cellular pathways in the host-pathogen interaction (Lamb and Dixon 1997). The regulation of its production by Nox family NADPH oxidase enzyme (Augusto et al. 2002; Nathan and Hibbs 1991) is 

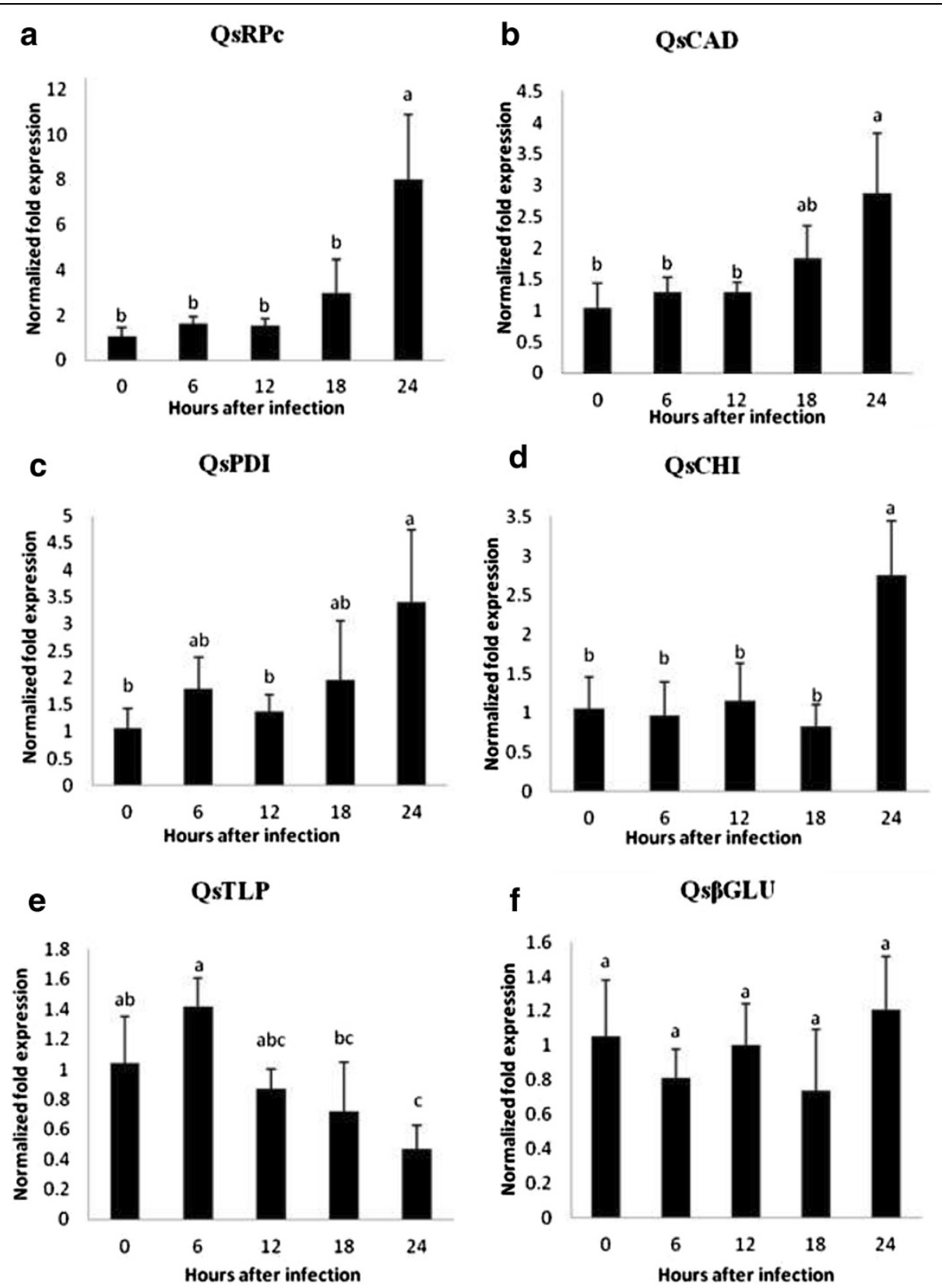

Figure 2 qRT-PCR expression profiles of six Quercus suber candidate genes, CC-NBS-LRR resistance protein (QsRPC: a), cinnamyl alcohol dehydrogenase2 (QsCAD2: b), protein disulphide isomerase (QsPDI: c), chitinase (QsCHI: $d$ ), thaumatin-like protein (QsTLP: $e$ ), and 1,3-B-glucanase (QsGlu: f). Q. suber roots were infected with P. cinnamomi in a $24 \mathrm{~h}$ time course of gene expression. Gene expression (y-axis) was calculated as the ratio between the transcript number of the $Q$. suber target genes and the geometric mean of transcript copies of selected housekeeping genes [RNA polymerase II (QsRP II) and clathrin adaptor complexes medium subunit family protein (QsCACS)]. Statistically significant differences $(P<0.05)$ between infected and non-infected (control) plants are indicated with different letters. Error bars represent the standard deviation of four biological replicates.

mediated by PDI, a redox sensitive protein that is induced during pathogen infection. The importance of the role of PDI in the control of different steps of infection processes is supported by its well described participation in the pathogen attachment-internalization and antigen processing in the endoplasmic reticulum (ER)/phagosome (Garin et al. 2001; Muller-Taubenberger et al.
2001). Rapid induction of PDI in wheat after fungal inoculation during early response has been previously reported (Ray et al. 2003). Also, in another study, PDI were up-regulated in lemon plants in response to Citrus huanglongbing (HLB) disease (Nwugo et al. 2013).

Chitinases are hydrolytic enzymes which can play a role in weakening and decomposing of fungal cell walls 
(Selitrennikoff 2001; Van Loon and Van Strien 1999). Chitinase accumulates around fungal hyphal material in planta (Benhamou et al. 1990; Wubben et al. 1992). Alone or in a combination with $1,3-\beta$-glucanase the enzyme was shown to cause the lysis of hyphal tips resulting in in-vitro inhibition of various fungi growth (Broglie et al. 1991; Mauch and Staehelin 1989; Schlumbaum et al. 1986). Furthermore, transgenic plants with induced chitinase levels are able to reduce the damage caused by the pathogens (Broglie et al. 1991). Moreover, it was reported that chitinases inhibit zoospore germination in Phytophthora (Young and Hwang 1996).

Yan et al. (2008) reported the existence of chitin in cell walls of Pythium aphanidermatum although at half the extent of fungal cell walls. Furthermore, Sharma et al. (2009) reported that in taro plant inoculated with $P$. colocasiae there was induction of a putative chitinase gene. This suggests the importance of chitinase in the resistance against this oomycete. It is also well documented that plant chitinases are both directly or indirectly involved in plant resistance towards many fungal pathogens (Schlumbaum et al. 1986). Sequence analysis revealed a coding region with a size of $951 \mathrm{bp}$ encoding 316 amino acid (GenBank accession no: KF704743) with 82\% homology to Fragaria vesca subsp. vesca chitinaselike protein 2-like. Within a family of 19 chitinases most are found mainly in plants but some are found in bacteria as well. Structural analysis reveals that this family together with a family comprising 46 chitosanases is similar to several lysozymes (Robertus and Monzingo 1999). The significant up-regulation of $Q$. suber chitinase during $P$. cinnamomi root infection suggests the importance of this enzyme in plant defence against the pathogen attack and constitutes probably, an effective response to lessen P. cinnamomi damage.

Systematic Acquired Resistance (SAR) in plants is found to correlate with induction of a set of putative defence genes including PR proteins (Linthorst 1991). One group of PR proteins (PR-5) is designated as thaumatinlike proteins based on the proteins extensive homology with thaumatin, a sweet-tasting protein from Thaumatococcus daniellii (Cornelissen et al. 1986). In Arabidopsis, SAR has been demonstrated to occur against pathogens and this resistance was correlated with induction of PR proteins including a thaumatin-like protein (Uknes et al. 1992). The thaumatin-like proteins purified from different plant systems have been shown to inhibit the growth of fungal pathogens in vitro (Vigers et al. 1991; Woloshuk et al. 1991) and among the defence-related proteins, thaumatin-like proteins (TLPs) are well known to function as anti-fungal proteins (Kim et al. 2009). The cDNAAFLP analysis revealed a gene coding for thaumatin-like protein (GenBank accession no: KF704742) from Q. suber. A 750 bp coding sequence region that showed $80 \%$ sequence similarity with Cucumis sativus thaumatin-like protein [(LOC101227447), mRNA (XM_004163769.1)] was resolved. TLPs are three-domain, crescent-fold structures with either an electronegative, electropositive, or neutral cleft occurring between domains I and II. The strong electronegative character of the cleft is presumably responsible for the antifungal activity of this protein (Leone et al. 2006). Some TLPs have the capacity to hydrolyze the 1,3-beta glucans commonly found in fungal walls (Grenier et al. 1999). Most typical TLPs described to date generally possess 16 conserved cysteine residues that form eight disulfide bonds (Ghosh and Chakrabarti 2008). Interestingly, contrary to reports from prior studies, the present study showed a general reduction in the production of the Q. suber thaumatin-like protein within 24 hours post-infection. This suggests that $P$. cinnamomi might suppress this host defence response processes to facilitate invasion, or alternatively that the induction of the production of this protein does not take place within $24 \mathrm{hpi}$.

Plants produce a variety of hydrolytic enzymes including chitinases, proteases and also glucanases, in defence against pathogens (Stintzi et al. 1993). 1,3- $\beta$-glucanases (glucan endo-1,3-glucosidases, $\beta-1,3-G s$ ) are hydrolytic enzymes that catalyse the hydrolysis of 1,3- $\beta$-D-glucosidic linkages in $\beta$-1,3-glucans in the pathogen cell wall; they are found in bacteria, fungi, metazoan (Bachman and McClay 1996) and viruses (Sun et al. 2000). In addition they were shown to be involved in cell division, pollen development and tube growth, regulation of plasmodesmata signalling, cold response, seed germination, and maturation (Hoj and Fincher 1995; Leubner-Metzger 2003, Leubner-Metzger and Meins 1999). Thus, $\beta-1,3-G$ s play major roles in developmental plant stages. The sequence of the gene coding for a 1,3- $\beta$-glucanase protein (GenBank accession no: KF704744) revealed a region with $1230 \mathrm{bp}$ encoding 409 amino acid and showed $74 \%$ homologous to Ricinus communis glucan endo-1,3- $\beta$-glucosidase. In this study, $1,3-\beta$-glucosidase gene expression, contrary to expectations, showed not to be significant in response to the $P$. cinnamomi infection. Therefore we can conclude that this $\beta-1,3-G s$ is related with developmental stages of the plant and not with the response to the pathogen.

We could not exclude, however, that given their membership in large gene families, the down-regulation of TLP and the lack of differential expression of $\beta-1,3-G s$ observed in the present study are due to the fact that we targeted paralogous sequences not involved in a defence response within the $24 \mathrm{hpi}$.

It is interesting to read our findings in light of the most recent transcriptome studies on Q. suber. Sebastiana et al. (2014) reported recently the differential expression of $Q$. suber genes comparing transcriptome of ectomycorrhizal (EM) colonized roots with nonsymbiotic roots. Proteins of the NBS-LRR family (namely, CC-NBS-LRR resistance 
gene subclasse) were found to be the most abundant products of differentially expressed genes (namely, upregulated). Their involvement in a response to EM colonization, suggests that not only they detect pathogens like $P$. cinnamomi as observed in our work but also fungi engaged in a mutualistic association.

However, QsCAD2, QsPDI, QsTLP, QsCHI and QsGlu were not found to be differentially expressed as a consequence of the EM colonization.

As a matter of fact it was not expected to observe upregulation of chitinase and 1,3- $\beta$-glucanase as these enzymes are involved in the lysis of hyphal tips and would inhibit mycorrhization. The same applies to TLPs whose activity against fungi proteins has been described (Kim et al. 2009). Also, cinnamyl alcohol dehydrogenases appears not to participate in the phenylpropanoid metabolism suggesting mycorrhization does not trigger cell wall reinforcement that would oppose hyphae penetration and the success of colonization. Nevertheless, it was expectable to observe QsPDI differential expression as the enzyme is involved in the response to the oxidative burst that was shown to occur in EM establishment, at least in Castanea sativa (Baptista et al., 2007). Also, Tarkka et al. (2013) found chitinase to be down-regulated in Q. robur mycorrhizal roots and genes related to phenylpropanoid metabolism depleted. Overall, these studies show that plant defences are attenuated in the mature oak EMs.

Interestingly, beneficial rhizobacteria appear to stimulate plant defences as it was recently shown in Q. robur challenged with $M$. alphitoides (Kurth et al., 2014). In this study, a large number of defence-related genes were differentially expressed in plants co-inoculated with a nonpathogenic Streptomyces sp. strain AcH 505 and oak powdery mildew. An identified CC-NBS-LRR gene was down-regulated compared to plants non-inoculated or inoculated either with the bacterium or with the fungus; no other genes from this family were reported. This observation and the above results show the complexity of the mechanisms in which this family of resistance genes appear to be involved. Cinnamyl alcohol dehydrogenase and one chitinase were up-regulated at the same level in plants inoculated either with $\mathrm{AcH} 505$ or oak powdery mildew or co-inoculated as compared to non-inoculated, in agreement with our results. No mention is made to the other genes studied in the present work.

In this study, we provide a brief insight into the expression pattern of some putative cork oak defence related genes during root infection by $P$. cinnamomi. The identification of these genes is a useful contribution to design and implement screening strategies aiming at the future development of breeding lines. Furthermore, in this study and for the first time a set of potential reference genes were analyzed and validated in root tissues for qRT-PCR normalization in the Phytophthora-Q. suber pathosystem. This is an important issue as the choice of suitable reference genes in any new experimental system is absolutely crucial in qRT-PCR.

\section{Additional file}

Additional file 1: Similarity of selected differentially expressed TDFs in the Quercus suber-Phytophthora cinnamomi interaction with sequences detected using blastn/tblastx (Altschul et al. 1997) and their annotation.

\section{Competing interests}

The authors declare that they have no competing interests.

\section{Authors' contributions}

All contributions to this paper were made by GE. Work supervision and revision of the manuscript for scientific and factual contents were done by AC. Both authors discussed the results, read and approved the final manuscript.

\section{Acknowledgements}

This work was supported by project PTCD/AGR-AAM/68628/2006 and grants from Fundação para a Ciência e Tecnologia (FCT) (SFRH/BD/76979/2011) and from Erasmus Mundus (EM8) program awarded to Ghazal Ebadzad.

\section{Author details}

${ }^{1}$ Faculdade de Ciências e Tecnologia, Universidade do Algarve, Campus de Gambelas, 8005-139 Faro, Portugal. ${ }^{2}$ Centre for Mediterranean Bioresourses and Food, FCT, Universidade do Algarve, Campus de Gambelas, 8005-139 Faro, Portugal.

Received: 14 June 2014 Accepted: 9 October 2014

Published: 17 October 2014

\section{References}

Ainsworth C (1999) Isolation of RNA from floral tissue of Rumex acetosa (Sorrel). Plant Mol Biol Rep 12(4):198-203

Altschul SF, Madden TL, Schäffer A, Zhang J, Zhang Z, Miller W, Lipman DJ (1997) Gapped BLAST and PSI-BLAST: a new generation of protein database search programs. Nucleic Acids Res 25:3389-3402

Asif MH, Dhawan P, Nath PA (2000) Simple procedure for the isolation of high quality RNA from ripening banana fruit. Plant Mol Biol Rep 18(2):109-115

Augusto O, Bonini MG, Amanso AM, Linares E, Santos CCX, De Menezes SL (2002) Nitrogen dioxide and carbonate radical anion: two emerging radicals in biology. Free Radical Biolo and Med 32(9):841-859

Ausubel FM, Brent R, Kingston RE, Moore DD, Seidman JG, Smith JA, Struhl K (1994) Current Protocols in Molecular Biology. Greene Publishing Associates and Wiley-Interscience, New York

Bachem CW, Oomen RJFJ, Visser RGF (1998) Transcript imaging with CDNA-AFLP: a step-by-step protocol. Plant Mol Biol Reporter 16:157-173

Bachman ES, McClay DR (1996) Molecular cloning of the first metazoan beta-1,3 glucanase from eggs of the sea urchin Strongylocentrotus purpuratus. Proc Natl Acad Sci U S A 93:6808-6813

Baptista P, Martins A, Salomé Pais M, Tavares RM, Lino-Neto T (2007) Involvement of reactive oxygen species during early stages of ectomycorrhiza establishment between Castanea sativa and Pisolithus tinctorius. Mycorrhiza 17:185-193

Benhamou N, Koosten MHAJ, De Wit PJGM (1990) Subcellular localization of chitinase and of its potential substrate in tomato root tissues infected by Fusarium oxysporum f. sp. racidis-Iycopersici. Plant Physiol 92:1108-1120

Brasier C (2003) Phytophthoras in European Forests: Their Rising Significance, Sudden Oak Death Online Symposium., www.apsnet.org/online/SOD (website of The American Phytopathological Society). doi:10.1094/SOD-2003-CB

Brasier CM, Robredo F, Ferraz JFP (1993) Evidence for Phytophthora cinnamomi involvement in Iberian oak decline. Plant Pathol 42:140-145

Breyne P, Zabeau M (2001) Genome-wide expression analysis of plant cell cycle modulated genes. Curr Opin Plant Biol 4:136-142

Broglie K, Chet I, Holliday M, Cressman R, Biddle P, Knowlton S, Mauvais CJ, Broglie R (1991) Transgenic plants with enhanced resistance to the fungal pathogen Rhizoctonia solani. Science 254:1194-1197 
Caetano P (2007) Envolvimento de Phytophthora Cinnamomi no Declínio de Quercus Suber e Q. Rotundifolia: Estudo da Influência de Factores Bióticos e Abióticos na Progressão da Doença. Possibilidades de Controlo Químico do Declínio. Ph.D. dissertation, Universidade do Algarve, Portugal, http:// sapientia.ualg.pt/handle/10400.1/400

Chandra A, Saxena R, Dubey A, Saxena P (2007) Change in phenylalanine ammonia lyase activity and isozyme patterns of polyphenol oxidase and peroxidase by salicylic acid leading to enhance resistance in cowpea against Rhizoctonia solani. Acta Physiol Plant 29:361-367

Chen L, Zhong HY, Kuang JF, Li JG, Lu WJ, Chen JY (2011) Validation of reference genes for RT-qPCR studies of gene expression in banana fruit under different experimental conditions. Planta 234(2):377-390

Coelho AC (2004) Study of the molecular biodiversity of Quercus suber and characterisation of genes involved in the defence response to the infection by Phytophthora cinnamomi). Ph.D. dissertation, University of Algarve, Portugal, http://hdl.handle.net/10400.1/5272

Coll NS, Epple P, Dangl JL (2011) Programmed cell death in the plant immune system. Cell Death Differ 18:1247-1256

Cornelissen BJC, Hooft van Huijsduijnen RAM, Bol JF (1986) A tobacco mosaic virus-induced tobacco protein is homologous to the sweet-tasting protein thaumatin. Nature 321:531-532

Demidenko NV, Logacheva MD, Penin AA (2011) Selection and validation of reference genes for quantitative real-time pcr in buckwheat (Fagopyrum esculentum) based on transcriptome sequence data. Plos One 6:e19434

Die JV, Rowland LJ (2013) Superior cross-species reference genes: a blueberry case study. PLoS ONE 8(9):e73354, doi:10.1371/journal.pone.0073354

Die JV, Roman B, Nadal S, Gonzalez-Verdejo Cl (2010) Evaluation of candidate reference genes for expression studies in Pisum sativum under different experimental conditions. Planta 232:145-153

Dudareva N, Cseke L, Blanc VM, Pichersky E (1996) Evolution of floral scent in Clarkia: novel patterns of S-linalool synthase gene expression in the C. breweri flower. Plant Cell 8:1137-1148

Expósito-Rodríguez M, Borges AA, Borges-Pérez A, Pérez JA (2008) Selection of internal control genes for quantitative real-time RT-PCR studies during tomato development process. BMC Plant Biol 8:131, doi:10.1186/1471-2229-8-131

Frolov AE, Goodwin AK, Favorova OO (2003) Differential gene expression analysis by DNA microarray technology and its application in molecular oncology. Mol Biol 37:486-494

Garin J, Diez R, Kieffer S, Dermine JF, Duclos S, Gagnon E, Sadoul R, Rondeau C, Desjardins M (2001) The phagosome proteome: insight into phagosome functions. J Cell Biol 152(1):165-180

Ghosh R, Chakrabarti C (2008) Crystal structure analysis of NP24-I: a thaumatin-like protein. Planta 228:883-890

Grenier J, Potvin C, Trudel J, Asselin A (1999) Some thaumatin-like proteins hydrolyse polymeric beta-1,3-glucans. Plant J 19(4):473-480

Gubler U (1988) A one tube reaction for the synthesis of blunt-ended double stranded cDNA. Nucl Acids Res 16:2726

Gubler U, Hoffman BJ (1983) A simple and very efficient method for generating cDNA libraries. Gene 25:263-269

Habu Y, lida S (1998) AFLP (amplified restriction fragment length polymorphism)based mRNA fingerprinting. Plant Biotechnol 15:249-251

Hammond-Kosack KE, Jones JDG (1997) Plant disease resistance genes. Annual review of plant physiology and plant. Mol Biol 48:575-607

Hinch JM, Clarke AE (1982) Callose formation in Zea mays as a response to infection with Phytophthora cinnamomi. Physiol Plant Pathol 21:113-124

Hoj PB, Fincher GB (1995) Molecular evolution of plant beta-glucan endohydrolases. Plant J 7:367-379

Horta M, Caetano P, Medeira C, Maia I, Cravador A (2010) Involvement of the $\beta$-cinnamomin elicitinin infection and colonisation of cork oak roots by Phytophthora cinnamomi. Eur J of Plant Pathol 127:427-436

Hulbert SH, Webb CA, Smith SM, Sun Q (2001) Resistance gene complexes: evolution and utilization. Annu Rev Phytopathol 39:285-312

Ingle R, Carstens M, Denby K (2006) Pamp recognition and the plant pathogen arms race. Bio Essays 28:880-889

Jones JD, Dangl JL (2006) The plant immune system. Nature 444:323-329

Jung T (2009) Beech decline in Central Europe driven by the interaction between Phytophthora infections and climatic extremes. Forest Pathol 39:73-94

Kim YJ, Shim JS, Lee JH, Jung SY, Sun H, In JG, Yang DC (2009) Isolation and characterization of a novel short-chain alcohol dehydrogenase gene from Panax ginseng. BMB Rep 42:673-678
Kohler A, Rinaldi C, Duplessis S, Baucher M, Geelen D, Duchaussoy F, Meyers BC, Boerjan W, Martin F (2008) Genome-wide identification of NBS resistance genes in Populus trichocarpa. Plant Mol Biol 66:619-636

Kurth F, Mailänder S, Bönn M, Feldhahn L, Herrmann S, Große I, Buscot F, Schrey SD, Tarkka MT (2014) Streptomyces-induced resistance against oak powdery mildew involves host plant responses in defense, photosynthesis, and secondary metabolism pathways. Mol Plant Microbe Interact 27(9):891-900

Lamb C, Dixon RA (1997) The oxidative burst in plant disease resistance. Annu Rev Plant Physiol Plant Mol Biol 48:251-275

Leone P, Menu-Bouaouiche L, Peumans WJ, Payan F, Barre A, Roussel A, Van Damme EJ, Rougé $P$ (2006) Resolution of the structure of the allergenic and antifungal banana fruit thaumatin-like protein at 1.7-A. Biochimie $88: 45-52$

Leubner-Metzger G (2003) Functions and regulation of beta-1,3-glucanases during seed germination, dormancy release and after-ripening. Seed Sci Res 13:17-34

Leubner-Metzger G, Meins FJ (1999) Functions and Regulation of Plant Beta-1, 3-Glucanases (PR-2). In: Datta SK, Muthukrishnan S (eds) Pathogenesis-Related Proteins in Plants. CRC Press LLC, Boca Raton (FL), pp 49-76

Linthorst HJM (1991) Pathogenesis-related proteins of plants. Crit Rev Plant Sci 10:123-150

Marum L, Miguel A, Ricardo CP, Miguel CM (2012) Reference gene selection for quantitative real-time PCR normalization in Quercus suber. PLoS ONE 7(4): e35113, doi:10.1371/journal.pone.0035113

Mauch F, Staehelin LA (1989) Functional implications of the subcellular localization of ethylene-induced chitinase and $\beta$-1,3-glucanase in bean leaves. The Plant Cell 1:447-457

Meyers BC, Dickerman AW, Michelmore RW, Sivaramakrishnan S, Sobral BW, Young ND (1999) Plant disease resistancegenes encode members of an ancient and diverse protein family within the nucleotide-binding superfamily. Plant J 20:317-332

Meyers BC, Kozik A, Griego A, Kuang H, Michelmore RW (2003) Genome-wide analysis of NBS-LRR-encoding genes in Arabidopsis. Plant Cell 15:809-834

Migocka M, Papierniak A (2011) Identification of suitable reference genes fo studying gene expression in cucumber plants subjected to abiotic stress and growth regulators. Mol Breeding. doi:10.1007/s11032-11010-19487-11030.

Milcevicova R, Gosch C, Halbwirth H, Stich K, Hanke MV, Peil A, Flachowsky H, Rozhon W, Jonak C, Oufir M, Hausman JF, Matusikova I, Fluch S, Wilhelm E (2010) Erwinia amylovora-induced defence mechanisms of two apple species that differ in susceptibility to fire blight. Plant Sci 179:60-67

Mills JC, Roth KA, Cagan RL, Gordon JI (2001) DNA microarrays and beyond: completing the journey from tissue to cell. Nat Cell Biol 3:e175-e178

Money T, Reader S, Qu LJ, Dunford RP, Moore G (1996) AFLP-based mRNA fingerprinting. Nucl Acids Res 24:2616-2617

Moreira-Marcelino ACM (2001) Aspectos da Interacção Entre Phytophthora Cinnamomi e a Doença do Declínio em Q. suber e Q. rotundifolia. Ph.D. dissertation, University of Algarve, Portugal

Muller-Taubenberger A, Lupas AN, Li H, Ecke E, Gerisch G, Simmeth M (2001) Calreticulin and calnexin in the endoplasmic reticulum are important for phagocytosis. The EMBO J 20(23):6772-6782

Nathan CF, Hibbs JB (1991) Role of nitric oxide synthesis in macrophage antimicrobial activity. Curr Opin Immunol 3:65-70, doi:10.1016/0952-7915(91) 90079-G

Natividade JV (1950) Subericultura. Ministério da Economia, Direcção Geral dos Serviços Florestais e Aquícolas, Lisboa, 387 pages, https:/openlibrary.org/ works/OL7345873W/Subericultura

Neale DB, Kremer A (2011) Forest tree genomics: growing resources and applications. Nat Rev Genet 12(2):111-122

Nwugo CC, Duan Y, Lin H (2013) Study on citrus response to huanglongbing highlights a down-regulation of defence-related proteins in lemon plants upon 'Ca. Liberibacter asiaticus' infection. PLoS ONE 8(6):e67442, doi:10.1371/ journal.pone.0067442

Pausas JG, Pereira JS, Aronson J (2009) The Tree. In: Aronson J, Pereira JS, Pausas JG (eds) Cork oak Woodlands on the Edge: Conservation, Adaptive Management and Restoration. Island Press, Washington, DC

Plomion C, Fievet V (2013) Oak genomics takes off... and enters the ecological genomics era. New Phytol 199(2):308-310

Radwan O, Gandhi S, Heesacker A, Whitaker B, Taylor C, Plocik A, Kesseli R, Kozik A, Michelmore RW, Knapp SJ (2008) Genetic diversity and genomic distribution of homologs encoding NBSLRR disease resistance proteins in sunflower. Mol Genet Genomics 280:111-125 
Ray S, Anderson JM, Urmeev Fl, Goodwin SB (2003) Rapid induction of a protein disulfide isomerase and defence-related genes in wheat to the hemibiotrophic fungal pathogen Mycosphaerella graminicola. Plant Mol Biol 3:741-754

Robertus JD, Monzingo AF (1999) The structure and action of chitinases. EXS $87: 125-135$

Robinson LH, Cahill DM (2003) Ecotypic variation in the response of Arabidopsis thaliana to Phytophthora cinnamomi. Australas Plant Pathol 32:53-64

Rookes JE, Wright ML, Cahill DM (2008) Elucidation of defence responses and signalling pathways induced in Arabidopsis thaliana following challenge with Phytophthora cinnamomi. Physiol Mol Plant Pathol 72:151-161

Rozen S, Skaletsky H (2000) Primer3 on the WWW for general users and for biologist programmers. Methods Mol Biol 132:365-386

Sambrook J, Russell D (2001) Molecular Cloning: A Laboratory Manual, 3rd edn. Cold Spring Harbor Laboratory, Cold Spring Harbor, NY

Schlumbaum AF, Mauch F, Vögeli U, Boller T (1986) Plant chitinases are potent inhibitors of fungal growth. Nature 324:365-367

Schmidt G, Delaney S (2010) Stable internal reference genes for normalization of real-time RT-PCR in tobacco (Nicotiana tabacum) during development and abiotic stress. Mol Genet Genomics 283:233-241

Sebastiana M, Vieira B, Lino-Neto T, Monteiro F, Fiqueiredo A, Sousa L, Pais MS, Tavares R, Paulo O (2014) Oak root response to ectomycorrhizal symbiosis establishment: RNA-Seq derived transcript identification and expression profiling. PLoS ONE 9(5):e98376, doi:10.1371/journal.pone.0098376

Selitrennikoff CP (2001) Antifungal proteins. Appl Env Microbiol 67:2883-2894

Sharma K, Mishra AK, Misra RS (2009) Identification and characterization of differentially expressed genes in the resistance reaction in taro infected with Phytophthora colocasiae. Mol Biol Rep 36:1291-1297

Shuman S (1994) Novel approach to molecular cloning and polynucleotide synthesis using vaccinia DNA topoisomerase. J Biol Chem 269:32678-32684

Soriano J, Vilanova S, Romero C, Llácer G, Badenes ML (2005) Characterization and mapping of NBS-LRR resistance gene analogs in apricot (Prunus armeniaca L.). Theor Appl Genet 110:980-989

Stintzi A, Heitz T, Prasad V, Wiedemann-Merdinoglu S, Kauffmann S, Geoffroy P, Legrand M, Fritig B (1993) Plant 'pathogenesis-related' proteins and their role in defence against pathogens. Biochimie 75:687-706

Sun L, Gurnon JR, Adams BJ, Graves MV, Van Etten $\sqcup$ (2000) Characterization of a beta-1,3-glucanase encoded by chlorella virus PBCV-1. Virol 276:27-36

Tarkka MT, Herrmann S, Wubet T, Feldhahn L, Recht S, Kurth F, Mailänder S, Bönn M, Neef M, Angay O, Bacht M, Graf M, Maboreke H, Fleischmann F, Grams TEE, Ruess L, Schädler M, Brandl R, Scheu S, Schrey SD, Grosse I, Buscot F (2013) OakContigDF159.1, a reference library for studying differential gene expression in Quercus robur during controlled biotic interactions: use for quantitative transcriptomic profiling of oak roots in ectomycorrhizal symbiosis. New Phytol 199(2):529-540

Tong ZG, Gao ZH, Wang F, Zhou J, Zhang Z (2009) Selection of reliable reference genes for gene expression studies in peach using real-time PCR. BMC Mol Biol 10:13, doi:10.1186/1471-2199-10-71

Uknes S, Mauch-Mani B, Moyer M, Potter S, Williams S, Dincher S, Chandler D, Slusarenko A, Ward E, Ryals J (1992) Acquired resistance in Arabidopsis. Plant Cell 4:645-656

Van Loon LC, Van Strien EA (1999) The families of pathogenesis-related proteins, their activities, and comparative analysis of PR-1 type proteins. Physiol Mol Plant Pathol 55:85-97

Venkatesh B, Hettwer U, Koopmann B, Karlovsky P (2005) Conversion of cDNA differential display results (DDRT-PCR) into quantitative transcription profiles. BMC Genomics 6(51), doi:10.1186/1471-2164-6-51

Vieira Dos Santos C, Rey P (2006) Plant thioredoxins are key actors in the oxidative stress response. Trends Plant Sci 11:329-334

Vigers AJ, Roberts WK, Selitrennikoff CP (1991) A new family of plant antifungal proteins. Mol Plant-Microbe Interact 4:315-323

Walker NJ (2002) A technique whose time has come. Science 296:557-559

Woloshuk CP, Meulenhoff EJS, Sela-Buurlage M, Van den Elzen PJM, Cornelissen BJC (1991) Pathogen-induced proteins with inhibitory activity toward Phytophthora infestans. Plant Cell 3:619-628

Wubben JP, Joosten MHAJ, Van Kan JAL, De Wit PJGM (1992) Subcellular localization of plant chitinase and $\beta$-1, 3-glucanases in Cladosporium fulvum (spn. Fulvia fulva) infected tomato leaves. Physiol Mol Plant Pathol 41:23-32

Xu M, Zhang B, Su X, Zhang S, Huang M (2011) Reference gene selection for quantitative real-time polymerase chain reaction in Populus. Anal Biochem 408:337-339
Yan RX, Hou JH, Ding DF, Guan WQ, Wang CY, Wu ZQ, Li MG (2008) In vitro antifungal activity and mechanisms of action of chitinase against four plant pathogenic fungi. J Basic Micro Biol 48:293-301

Young JK, Hwang BK (1996) Purification, N-terminal amino acid sequencing and anti-fungal activity of chitanases from pepper stems treated with mercuric chloride. Physiol Mol Plant Pathol 48:417-432

Zabeau M, Vos P (1993) Selective Restriction Fragment Amplification: A General Method for DNA Fingerprinting, European Patent Application 924,026,297

GenEx Software 5. 4. 3 MultiD Analyses AB. Odinsgatan 28, SE-411 03, Gothenburg, Sweden

The Fagaceae Genomic Tools Project., http://www.fagaceae.org

doi:10.1186/2193-1801-3-613

Cite this article as: Ebadzad and Cravador: Quantitative RT-PCR analysis of differentially expressed genes in Quercus suber in response to Phytophthora cinnamomi infection. SpringerPlus 2014 3:613.

\section{Submit your manuscript to a SpringerOpen ${ }^{\odot}$ journal and benefit from:}

- Convenient online submission

- Rigorous peer review

- Immediate publication on acceptance

- Open access: articles freely available online

- High visibility within the field

- Retaining the copyright to your article

Submit your next manuscript at $>$ springeropen.com 